\title{
Carrying Capacity of Agriculture Sector Based on Commodities' Production in Kulonprogo Regency
}

\author{
Zuhud Rozaki ${ }^{1, *}$ \\ ${ }^{1}$ Department of Agribusiness, Universitas Muhammdiyah Yogyakarta, Yogyakarta, Indonesia \\ *Corresponding author. E-mail : zaki@umy.ac.id
}

\begin{abstract}
Becoming one of leading sectors in supporting national economic, especially low middle people, agriculture has multi-function in regional development. This study aims to analyze the carrying capacity of agriculture sector based on commodities' production in Kulonprogo Regency. Those commodities come from agriculture, horticulture, plantation, livestock and aquaculture. Quantitative method was used based on supply and demand of land. The calculation was based on regulation by Ministry of Life Environment, Indonesia. Results show that the carrying capacity of agriculture sector has enough supportability for demand. The land availability is $108,019.05$ ha and land requirement is 107,492 , it means the carrying capacity is surplus. The demand of agriculture products in term or keeping land for human and environment come to problem if not balance. Both supply and demand must meet in the balance and support each other.
\end{abstract}

Keywords: agriculture sector, carrying capacity, commodities' production, environment

\section{INTRODUCTION}

Indonesia as the developing country need to grow based on his own strength. Today's condition is forcing every party to be involved in the development efforts. Agriculture, industry and service sector need do balance deeds in order to national development can reach every level of country's aspect, from national to local level.

National economic growing cannot be separated from population, natural resources and economic activities [1]. It is unavoidable fact that agriculture still become the choice of majority people in Indonesia as economic generator especially in local level. As a country that rural areas are dominated all around area, agriculture is leading in providing food and economic aspect for the people.

Developing regional potency by developing agriculture sector is better choice for Indonesia that majority of his people are working in agriculture or related sectors [2]. Currently, industry, housing and other human activities are taking more land. These often take agriculture land, so agriculture land is decreasing. It can caused the carrying capacity of agriculture sector.

Food requirement is increasing, while agriculture land doesn't. It means that the carrying capacity of agriculture sector need to be analysed. Carrying capacity in each region has different things to be considered. For example in India, common commodities for analysing carrying capacity or agriculture sector are people and livestock [3].

Carrying capacity calculation is quite difficulty for exact result due to some variables associated with the production and consumption which is difference from each region [3]. Due to those differences, comparative and competitive advantage of each region must be considered [4]. The carrying capacity of agriculture sector is important to be analysed to know the condition of agriculture in certain area, whether it is surplus or deficit [5].

Indonesia has own regulation for deciding the carrying capacity of the land to live with decent condition for his people: Regulation no 17 year 2009 by Ministry of Life Environment, Indonesia. Kulonprogo Regency has 586.28 $\mathrm{km}^{2}$ area with 421,295 people inhabitants. Agriculture's main commodity is rice, in 2017 this regency could produce 113,359 ton paddy from $18,626.6$ Ha total paddy field area [6]. But it doesn't mean that this regency has surplus land for their people living. This research aims to analyse the carrying capacity of agriculture sector in Kulonprogo Regency using this regulation.

\section{METHODS}

Descriptive method was used in this research. Secondary data regarding the commodities' production in agriculture, horticulture, plantation, livestock, vegetable, herbs, ornamental plant, timber, and fishery. Those data were taken from Kulonprogo Regency in Number 2018. Price for each commodity was analysed from various sources.

Regulation no 17 year 2009 by Ministry of Life Environment, Indonesia was used to analyse land availability was analysed, land requirement and carrying capacity status. Below is the formula:

Land Availability:

$\mathrm{SL}=\frac{\sum(P i x H i)}{H b} \times \frac{1}{P t v b}$

Where:

$\mathrm{S}_{\mathrm{L}} \quad=$ Land Availability (Ha)

$\mathrm{Pi} \quad=$ Total production of commodities (converted to IDR 
$\begin{array}{ll}\mathrm{Hi} & =\text { Price of each commodity (IDR) } \\ \mathrm{Hb} & =\text { Price of rice in the producer level (IDR) } \\ \mathrm{Ptvb} & =\text { Production of rice }(\mathrm{kg} / \mathrm{Ha})\end{array}$

Land Requirement:

$\mathrm{D}_{\mathrm{L}}=\mathrm{N} \times \mathrm{KHL}_{\mathrm{L}}$

Where:

$\mathrm{D}_{\mathrm{L}} \quad=$ Total of land requirement in equal with rice

(Ha)

$\mathrm{N}=$ Population (people)

$\mathrm{KHL}_{\mathrm{L}}=$ Land requirement for decent life for one person based on Regulation no 17 year 2009 by Ministry of Life Environment, Indonesia (Ha)

Note:

1. Land requirement for decent life per people is a decent life per people divided local rice productivity

2. Decent life need per people is assumed as 1 ton rice/ capita/ year.

3. Land requirement for decent life per people $\left(\mathrm{KHL}_{\mathrm{L}}\right)=1$ ton equal with rice divided rice productivity.

Status of Carrying Capacity:

$\mathrm{S}_{\mathrm{L}}>\mathrm{D}_{\mathrm{L}}$, means carrying capacity is surplus

$\mathrm{S}_{\mathrm{L}}<\mathrm{D}_{\mathrm{L}}$, means carrying capacity is deficit

\section{RESULTS AND DISCUSSION}

\section{a. Commodities' production}

Kulonprogo Regency is region that doesn't have many industry. Tourism sector currently is being developed. But it cannot stand alone, and many of tourism sector need to be supported by agriculture sector. Some places are developing tourism village that combine tourism and agriculture. Agriculture in this regency has various commodities that support people living. These also supported by horticulture, vegetable, herb, ornamental plant, plantation, timber, livestock and fishery.

Table 1. Agriculture's Production

\begin{tabular}{|l|r|}
\hline Commodity & Production (Ton) \\
\hline Paddy wetland & 113,107 \\
\hline Paddy dryland & 252 \\
\hline Maize & 29,168 \\
\hline Cassava & 73,702 \\
\hline Sweet potatoes & 248 \\
\hline Peanut & 647 \\
\hline Soybean & 3,129 \\
\hline Mungbean & 179 \\
\hline
\end{tabular}

Source: Badan Pusat Statistik 2018

Agriculture commodities that supporting people life in Kulonprogo Regency are paddy, maize, cassava, sweet potatoes, peanut, soybean and mungbean (as seen in Table 1). Paddy wetland still dominating the production among other commodities with production 113,107 ton.. Mungbean is the fewest production among others with production 179 ton, but this commodity plays good role in providing nutrition to the people.
Table 2. Horticulture's Production

\begin{tabular}{|l|r|}
\hline Commodity & Production (Quintal) \\
\hline Avocado & 15,365 \\
\hline Manggo & 65,477 \\
\hline Rambutan & 50,900 \\
\hline Duku & 7,186 \\
\hline Big Orange & 2,655 \\
\hline Orange & 12,920 \\
\hline Starfruit & 2,904 \\
\hline Mangosteen & 11,906 \\
\hline Sour soup & 1,522 \\
\hline Durian & 42,957 \\
\hline Guava & 12,889 \\
\hline Bread fruit & 37,308 \\
\hline Sapodilla & 7,217 \\
\hline Papaya & 26,359 \\
\hline Banana & 211,280 \\
\hline Pineapple & 2,294 \\
\hline Salacia & 19,447 \\
\hline Jack fruit & 55,440 \\
\hline Ginetum gnemon & 65,552 \\
\hline Petai & 18,636 \\
\hline Source: Badan Pusat Statistik 2018 & \\
\hline
\end{tabular}

Table 3. Vegetable's Production

\begin{tabular}{|l|r|}
\hline Commodity & Production (Quintal) \\
\hline Onion & 53,134 \\
\hline Scallion & 40 \\
\hline Chinese cabbage & 13,234 \\
\hline Cowpea & 77 \\
\hline Flatnut & 6,499 \\
\hline Water melon & 56,390 \\
\hline String bean & 4,858 \\
\hline Chili & 201,848 \\
\hline Hot chili & 19,894 \\
\hline Tomatoes & 1,296 \\
\hline Eggplant & 8,664 \\
\hline Melon & 155,239 \\
\hline Cabbage flower & 171 \\
\hline Water spinach & 7,154 \\
\hline Spinach & 1,733 \\
\hline Black potatoes & 1,146 \\
\hline Source: Badan Pusat Statistik 2018 &
\end{tabular}

Meanwhile horticulture's commodities area avocado, mango, rambutan, duku, big orange, orange, starfruit, mangosteen, sour soup, durian, guava, bread fruit, sapodilla, papaya, banana, pineapple, salacia, jack fruit, 
ginetum gnemon and petai (as seen in Table 2). The most produced commodity is banana with 211,280 ton. This commodity is popular commodity because quite easy to be planted and easy to be sold or consumed by them self.

Kulonprogo regency in mountainous area, so vegetable in some areas are suitable to be planted. Vegetable's commodities in this regency are onion, scallion, chinese cabage cowpea, flatnut, water melon, string bean, chili, hot chili, tomatoes, eggplant, melon, cabbage flower, water spinach, spinach and black potatoes (as seen in Table 3). Some areas of this regency produced many chili, it is shown by the chili production is dominating from other commodities with 201,848 quintal.

Table 4. Herbs and Spices Production

\begin{tabular}{|l|r|}
\hline Commodity & Production (Kg) \\
\hline Ginger/ jahe & $3,699,905$ \\
\hline Galingale/ laos & 981,297 \\
\hline Kencur & $1,712,134$ \\
\hline Tumeric/ kunyit & $2,839,523$ \\
\hline Ginger family/ lempuyang & 493,416 \\
\hline Medicinal root/ temu kunci & 263,633 \\
\hline Wild ginger/ temulawak & $1,215,562$ \\
\hline Black ginger/ temu ireng & 687,619 \\
\hline Medicinal plant/ keji beling & 43,497 \\
\hline Medicinal plant/ sambiloto & 78,927 \\
\hline Piper betler/ dlingo & 46,505 \\
\hline Cardamom/ kapulogo & $1,222,644$ \\
\hline Morinda/ mengkudu & 115,511 \\
\hline
\end{tabular}

Source: Badan Pusat Statistik 2018

Tropic country such as Indonesia has advantage in growing herbs and spices. It is supported by high herbs and spices consumption. Kulonprogo Regency also has herbs and spices quite many, they are ginger (jahe), galingale (laos), kencur, turmeric (kunyit), lempuyang, temu kunci, wild ginger (temulawak), black ginger (temu ireng), keji beling, sambiloto, piper betler (dlingo), cardamom (kapulogo), and morinda (mengkudu). The highest production of these commodities is ginger with 3,699,905 kg. Ornamental plant is dominated by orchid (table 5). Other ornamental plant is not significant in the production.

Table 5. Ornamental Plant's Production

\begin{tabular}{|l|r|}
\hline Ornamental plant Commodity & Production (Stem) \\
\hline Orchid & 305 \\
\hline
\end{tabular}

As a regency that has mountainous and dry area, this regency also has plantation plants, they area cocoa, coffee, coconut, clove, coryphe utanlamk, cashew, pepper, tea and patchouli (Table 6). These commodities usually become the side job. Such as cocoa that need good to technology to produce good cocoa powder, people only sell their cocoa bean to the distributor without processing it first. This regency can produce timber too, they are teak, sonokeling, mahagony, acacia and sengon (Table 7). These commodities take time to be harvested, so commonly only for side job to get more money.

Table 6. Plantation's Production

\begin{tabular}{|l|r|}
\hline Plantation Commodity & Production (Ton) \\
\hline Cocoa & 1,297 \\
\hline Coffee & 424 \\
\hline Coconut & 25,560 \\
\hline Clove & 643 \\
\hline Corypha utanlamk & 31 \\
\hline Cashew & 2 \\
\hline Pepper & 4 \\
\hline Tea & 842 \\
\hline Patchouli & 68 \\
\hline Source: Badan Pusat Statistik 2018 &
\end{tabular}

Table 7. Timber's Production

\begin{tabular}{|l|r|}
\hline Timber Commodity & Production (m3) \\
\hline Teak & 29510 \\
\hline Sonokeling & 468 \\
\hline Mahagony & 6450 \\
\hline Acacia & 9317.6 \\
\hline Sengon & 5100 \\
\hline
\end{tabular}

Source: Badan Pusat Statistik 2018

Table 8. Livestock's Production

\begin{tabular}{|l|r|}
\hline Livestock Commodity & Production \\
\hline Milk cow (female) & 30 \\
\hline Milk cow (male) & 1 \\
\hline Cow (female) & 43,609 \\
\hline Cow (male) & 7,970 \\
\hline Buffalo (female) & 64 \\
\hline Buffalo (male) & 23 \\
\hline Horse (Female) & 1 \\
\hline Horse (male) & 10 \\
\hline Goat (female) & 70,629 \\
\hline Goat (male) & 21,280 \\
\hline Sheep (female) & 16,904 \\
\hline Sheep (male) & 4,503 \\
\hline Pig (female) & 638 \\
\hline Pig (male) & 391 \\
\hline Layer chicken & $1,124,942$ \\
\hline Broiler chicken & $1,870,037$ \\
\hline Quail & 606,618 \\
\hline Duck & 140,756 \\
\hline Source: Badan Pusat Statistik 2018 & \\
\hline
\end{tabular}


For hilly places and dry area, commonly people growing livestock such as cow, while they are waiting the livestock ready to be sold, they are planting agriculture's commodities. Other livestock commodities are milk cow, buffalo, horse, goat, sheep, pig, domestic hens, layer chicken, broiler chicken, quail, duck and rabbit. The highest production come from broiler chicken with 1,870,037 (Table 8).

Because this regency doesn't have sea, so the fish that can be produced are mostly cultured fish such as goldfish, java barbus, nile tilapia, carp and cat fish. The most favourite and high demand is catfish, also this fish is quite easy to be cultured, so the highest production in term of fish is catfish with $8,868,814 \mathrm{~kg}$ (Table 9).

Table 9. Fishery's Production

\begin{tabular}{|l|r|}
\hline Fishery Commodity & Production (Kg) \\
\hline Goldfish & 3,750 \\
\hline Java barbus & 1,665 \\
\hline Nile tilapia & 741,788 \\
\hline Carp & $1,498,792$ \\
\hline Cat fish & $8,868,814$ \\
\hline
\end{tabular}

\section{b. Land availability}

This land availability really effected by commodities' production in agriculture sector. Based on Table 10, total point from all above commodities are IDR $4,233,588,284,750.00$. the price of rice is assumed IDR $10,000,00$ and rice production per ha is $3,919 \mathrm{~kg} / \mathrm{ha}$. Then the land availability in this regency is equal with $108,019.05$ ha. Higher the productivity and commodity price, will increase this value.

Table 10. Land Availability

\begin{tabular}{|c|c|c|c|}
\hline No & Component & Unit & Total \\
\hline 1. & $\sum \mathrm{Pi} \mathrm{xi}$ & $\mathrm{IDR}$ & $4,233,588,284,750.00$ \\
\hline 2. & $\mathrm{Hb}$ & $\mathrm{IDR}$ & $10,000.00$ \\
\hline 3. & $\mathrm{Ptvb}$ & $\mathrm{Kg} / \mathrm{Ha}$ & $3,919.30$ \\
\hline 4. & $\mathrm{~S}_{\mathrm{L}}$ & $\mathrm{Ha}$ & $108,019.05$ \\
\hline
\end{tabular}

\section{c. Land requirement}

People need land to live and get decent life, land requirement depends on the land area and the population. Of course the economic condition also effect it. The population of this regency is 421,295 people, and the land area to live for decent life is 0.26 ha. Total of land requirement to live in decent life status is 107,429 ha.

Table 11. Land Requirement

\begin{tabular}{|l|l|l|r|}
\hline No & Component & Unit & \multicolumn{2}{|c|}{ Total } \\
\hline 1. & $\mathrm{~N}$ & People & 421,295 \\
\hline 2. & $\mathrm{KHL}_{\mathrm{L}}$ & $\mathrm{Ha}$ & 0.26 \\
\hline 3. & $\mathrm{D}_{\mathrm{L}}$ & $\mathrm{Ha}$ & 107,492 \\
\hline
\end{tabular}

\section{d. Carrying capacity}

The land availability is $108,019.05$ ha and land requirement is 107,492 , it means the carrying capacity is surplus. This condition shows that agriculture sector can provide the people need regarding agriculture commodities. But the gap between land availability and land requirement is small, if no action to handle it, in the future can become deficit. Land used change due to the urban enlarging process such as for housing, industry, infrastructure, etc also effect the deficit status of carrying capacity [4].

\section{CONCLUSION}

Kulonprogo Regency has high variety in agriculture commodities. All are playing role in providing people need for agriculture products. The land availability is $108,019.05$ ha and land requirement is 107,492 , it means the carrying capacity is surplus. But government or other parties need to think how to develop agriculture in order to the surplus condition can be kept.

\section{ACKNOWLEDGMENT}

Author would like to express big gratitude to Universitas Muhammadiyah Yogyakarta for supporting this research.

\section{REFERENCES}

[1] I. W. Susanto, M. R. Anwar and Soemarno, "Analisis Daya Dukung Lingkungan Sektor Pertanain Berbasis Produktivitas di Kabupaten Bangli," Jur. Bum. Lest. Vol. 13, No. 1. Pp. 115123, 2013.

[2] V. K. Singh and R. D. Singh, "Agricultural development and regional carrying capacity measurement of agro-ecosystem in Jhabua tribal district in Madhya Pradesh" MPRA. No. 30565. posted 3 May 2011.

[3] A. Agustizar, C. Maryani and S. Sarwono, "Agricultural Land Carrying Capacity and Shift of Land Use in Upstream of Grompol Watershed, Central Java Province," IOP Conf. Ser.: Earth Environ. Sci. 145 012070, 2018.

[4] B. Venkateswarlu and J. V. N. S. Prasad, "Carrying capacity of Indian agriculture: issues related to rainfed agriculture," Cur. Sci. Vol. 102, No. 6, 882888,2012 .

[5] I. N. S. Wijaya, B. Rahadi, N. Lusiana and I. Maulidina, "Problem in application carrying capacity approach for land allocation assessment in Indonesian municipal spatial planning: A case of Kutai Kartanegara Regency," IOP Conf. Ser.: Earth Environ. Sci. 70012038

[6] Badan Pusat Statistik, "Kabupaten Kulonprogo Dalam Angka 2017,'

[7] Regulation no 17 year 2009 by Ministry of Life Environment, Indonesia

[8] O. Wijaya, "Strategi Pengembangan Komoditas Pangan Unggulan dalam Menunjang Ketahanan Pangan Wilayah (Studi Kasus di Kabupaten Batang, Propinsi Jawa Tengah)," AGRARIS: J. Agri. and Rur. Dev. Resc. Vol. 3 No. 1, 48-56, 2017. 